\title{
Få tannlegespesialister i distriktene
}

\author{
Tannhelsetjenesten i Norge består av en offentlig (25\%) og en privat \\ sektor (75\%). Det er store regionale forskjeller i tilgang på spesialister, \\ og kun et fåtall av disse jobber i det offentlige. Fylkeskommunen har \\ problemer med å ivareta det lovpålagte tilbudet til prioriterte grupper.
}

Den offentlige tannhelsetjenesten yter i hovedsak tjenester til grupper av befolkningen definert i lov om tannhelsetjenesten, og den private sektor tilbyr tjenester til den øvrige befolkningen. Fylkeskommunen skal både organisere forebyggende tiltak for hele befolkningen og gi et regelmessig og oppsøkende tilbud om tannhelsetjenester til barn og ungdom 0-18 år, psykisk utviklingshemmede, eldre langtidssyke og uføre i institusjon og hjemmesykepleie, ungdom som fyller 19 eller 20 år i behandlingsåret, samt andre grupper som fylkeskommunen har vedtatt å prioritere. Den offentlige tannhelsetjenesten kan i tillegg yte tjenester til voksent betalende klientell etter fylkeskommunens bestemmelser. Fylkeskommunen skal sørge for at tannhelsetjenester, herunder spesialisttjenester, er tilgjengelig for alle som bor eller midlertidig oppholder seg i fylket. Den er også pålagt et samordningsansvar for den offentlige (fylkeskommunale) tannhelsetjenesten og private tjenesteytere.

Om lag tre firedeler av tannlegeårsverkene utføres i privat sektor. Tannlegespesialister utdannes i sju fagdisipliner: kjeveortopedi, oral kirurgi og oral medisin, periodonti, pedodonti, endodonti, oral protetikk og kjeve- og ansiktsradiologi. De fleste spesialistene jobber i privatpraksis.

\section{Forekomst av tannlegespesialister}

Vi spurte alle fylkestannlegene våren 2007 om spesialisttjenesten i fylkene. Vi fikk svar fra 17 av 19 fylkestannleger. Bare $11 \%$ av alle spesialister jobbet $i$ den offentlige tannhelsetjenesten. Ifølge fylkestannlegene hadde befolkningens etterspørsel etter spesialisttannhelsetjenester økt i de fleste fylker de siste fem årene. Alle 17 fylker som svarte hadde offentlig ansatte eller privatpraktiserende spesialister i kjeveortopedi. I 15 fylker var det også spesialister i oral kirurgi og oral medisin og i periodonti. Spesialister i endodonti og i oral protetikk fantes i 12 fylker, pedodontister i sju fylker og kjeve- og ansiktsradiologer i tre fylker. Bare fire fylkestannleger mente det var tilstrekkelig med spesialister i deres fylke i forhold til befolkningens etterspørsel og tjenestebehov. Tre av disse var i Sør-Norge. 11 av fylkene mente de hadde behov for spesialister i endodonti, protetikk og kjeveortopedi.

Seks av respondentene mente den offentlige tannhelsetjenesten hadde ansatt for få spesialister. De mente dette delvis hadde sammenheng med at spesialistene ikke vil arbeide utenfor Oslo eller Bergen, og delvis med at fylket ikke hadde økonomiske midler til spesialisttjenester i offentlig sektor. Det ble stilt store forhåpninger til regionale kompetansesentre, som det i dag finnes to av som er i drift/delvis i drift og tre som er i planleggingsfasen. Fylkestannlegene hadde konkrete forbedringsforslag til å gjøre noe med mangelen på tannlegespesialister: desentralisert spesialistutdanning med lønn lik legenes spesialistutdanning. Spesialistutdanning av tannleger i Norge er en treårig fulltidsutdanning som foregår ved universitetene i Oslo og Bergen, og i Tromsø fra 2009. Kandidatene får ikke lønn under utdanningen. Det er en offentlig oppgave å utdanne tannlegespesialister i Norge og følgelig bør kandidatene lønnes. Både i Sverige og Finland har tannlegene lønn betalt av staten mens de er under spesialistutdanning.

14 av fylkestannlegene mente det var den offentlige tannhelsetjenestens ansvar å sørge for nødvendige tannhelsetjenester til de prioriterte gruppene, herunder også spesialisttjenester. Tre mente at basistannhelsetjenester var tilstrekkelig til disse gruppene. To påpekte at deres ansvar for spesialisttjenester kunne tolkes som et «sørge for»ansvar hvilket innebar spesialisttjenester $\mathrm{i}$ rimelig avstand fra bosted, dvs. at et tilbud i nabofylket kunne være tilstrekkelig. På spørsmålet om hvem som hadde ansvar for at også den øvrige befolkning kunne få nødvendig tannbehandling (inkludert spesialistbehandling), svarte ti at det var fylkets ansvar. To av dem mente ansvaret lå hos fylket, men at fylket i praksis ikke hadde virkemidler til å gjøre noe med situasjonen. Fire fylkestannleger mente at de privatpraktiserende tannlegene og Den norske tannlegeforening var ansvarlig. De resterende tre mente dette var et felles ansvar for staten og fylkeskommunene.

\section{Den nordiske modellen}

Den nordiske tannhelsemodellen med en omfattende offentlig sektor skiller seg markant fra modellene i det øvrige Europa, hvor tannhelsetjenester overveiende er private. I Sentral-Europa dekker nasjonale sykeforsikringer også tannhelsetjenester, mens forsikringsordninger er mer sjeldent i Sør-Europa, og marginalt i Øst-Europa (1). Den offentlige tannhelsetjenestens arbeidsfelt i Norge er betydelig smalere enn i nabolandene Sverige og Finland hvor alle voksne kan benytte seg av offentlige tannhelsetjenester om de vil (2). Det er likheter med systemet i Danmark, men der får alle voksne pasienter støtte via trygdeordninger. Bare en liten del av tannhelsetjenestene i Norge utløser trygderefusjon, mens for helse generelt dekkes en overveiende del av folketrygden. Årsaken til dette er noe uklar, men historiske forhold synes å spille en stor rolle. Behovet for endringer i tannhelsetjenesten er blitt løftet frem i Stortingsmelding 35 (3), der det konstateres at det $i$ tannhelsetjenesten er et regionalt fordelingsproblem, et sosialt fordelingsproblem og et behov for mer effektiv tjenesteproduksjon. De nylig gjennomførte endringer med fastlege- og sykehusreformene kan ha vært medvirkende til at man på politisk nivå har vært lite opptatt av problemstillinger innenfor tannhelsesektoren. Det er også kjent fra andre land med et privat helsesystem at tannlegeprofesjonen ikke spontant er interessert i å sparke i gang reformer som innebærer mer sosialt ansvar for helsesystemet.

\section{Konklusjon}

De regionale forskjellene i det spesialiserte tannhelsetjenestetilbudet er store, og det er sannsynlig at et stort antall spesialister i spesialisttette områder ikke utnyttes optimalt. Fylkestannlegene har sannsynligvis ikke rimelige muligheter til å ta ansvar for at hele befolkningen får nødvendige tannhelsetjenester. Mange synes å ha problemer med å ivareta det lovpålagte tilbudet til det prioriterte klientellet.

\section{Eeva Widström}

eeva.widstrom@uit.no

Institutt for klinisk odontologi

Det helsevitenskapelige fakultet

Universitetet i Troms $\emptyset$

9037 Tromsø

Ragnhild Nordengen

Tannhelsetjenestens kompetansesenter

for Nord-Norge (TkNN)

Tage Olsen

Alta tannklinikk

Oppgitte interessekonflikter: Ingen

Litteratur

1. Widström E, Eaton KA. Oral health care systems in the Extended European Union. Oral Health Prev Dent 2004; 2: 155-94.

2. Widström E, Ekman A, Aandahl SL et al. Development in oral health policy in the Nordic countries since 1990. Oral Health Prev Dent 2005: 3: 225-35.

3. Helse-og omsorgsdepartementet. Tilgjengelighet kompetanse og sosial utjevning. Framtidas tannhelsetjenester. St.meld. nr 35 (2006-2007). 